\title{
PENGARUH UKURAN PERUSAHAAN, LEVERAGE DAN LIQUIDITAS TERHADAP PROFITABILITAS DI PERUSAHAAN ESPERANCA TIMOR-OAN (ETO) DILI TIMOR-LESTE
}

\author{
Madalena Maria ${ }^{1}$ \\ L.P. Wiagustini ${ }^{2}$ \\ I.B.Panji Sedana ${ }^{3}$ \\ 1,2,3 Fakultas Ekonomi dan Bisnis Universitas Udayana (Unud), Bali - Indonesia \\ email: mcmaria1982@yahoo.com
}

\begin{abstract}
Financial performance is an analysis done to see the extent to which the company Esperanca Timor-oan has implemented by using the rules of financial performance is good and right.This study aim to determine the effect of firm size (Total asset), leverage (DER) and liquidity (QR) to profitability (ROA) in the company Esperanca Timor-Oan Unipessoal.Lda Dili East Timor. This research was conducted in the company ETO. Secondary date in this research report 2010-2012 financial year, . Testing the research hypotheses using multiple regression linear analysis techniques, with tools Statistical Package for the Application of the Social Sciences (SPSS) 21.0 Version.The results showed that: 1).the size of the company's significant negative effect on profitability, leverage significant positive effect on profitability, liquidity significant negative effect on profitability.
\end{abstract}

Key Words : Firm Size, Debt to Equity Ratio, Quick Ratio and Return On Asset

\begin{abstract}
ABSTRAK
Kinerja keuangan merupakan suatu analisis yang dilakukan untuk melihat sejauh mana perusahaan Esperanca Timor-Oan telah melaksanakan aturan- aturan pelaksanaan keuangan secara baik dan benar. Penelitian ini bertujuan untuk mengetahui pengaruh ukuran perusahaan (Total Asset), leverage (DER) dan likuiditas (QR) terhadap profitabilitas (ROA) diperusahaan Esperanca Timor-Oan Unipessoal.Lda Dili Timor-Leste.Penelitian ini dilakukan diperusahaan ETO. Data sekunder dalam penelitian ini laporan keuangan tahun 2010-2012, . Pengujian hipotesis penelitian menggunakan teknik analisis regresi linear berganda, dengan alat bantu Aplikasi Statistical Packege for the Social Sciences (SPSS) Versio 21.0. Hasil penelitian menunjukkan bahwa;1) ukuran perusahaan berpengaruh negatif signifikan terhadap profitabilitas, leverage berpengaruh positif signifikan terhadap profitabilitas dan likuiditas berpengaruh negatif tidak signifikan terhadap prfitabilitas.
\end{abstract}

Kata kunci: ukuran perusahaan, Debt to Equity Ratio, Quick Ratio dan Return On Asset 


\section{PENDAHULUAN}

Timor-leste merupakan salah satu Negara yang memiliki sumber daya alam yang melimpah khususnya minyak dan gas bumi. Namun demikian dalam memenuhi kebutuhan akan minyak, Timor leste masih mengimpor dari Negara lain seperti: Indonesia, Malaysia dan Singapur. Hal ini disebabkan oleh kemampuan sumber daya manusia yang masih terbatas, sehingga dalam memenuhi kebutuhan minyak dalam negeri dimonopoli oleh beberapa Perusahaan Swasta Nasional yang beroperasi dan salah satu Perusahaan Indonesia yaitu Pertamina.

Salah satu Perusahaan Swasta Nasional yang mengimpor minyak untuk memenuhi kebutuhan masyarakat khususnya kebutuhan minyak pemerintah (Government) dalam hal ini memenuhi kebutuhan minyak untuk Tenaga Pembangkit Listrik adalah Esperanca Timor Oan Unipesoal Lda. Dari sudut pandang manajemen, khususnya manajemen keuangan, perusahaan tersebut memiliki sumber-sumber dana internal perusahaan maupun Eksternal perusahaan, dalam memenuhi kebutuhan dana operasional perusahaan Esperanca Timor Oan Unipesoal Lda ini membutuhkan dana eksternal yaitu dana yang berasal dari pihak kreditur (bank), hal ini dikarenakan perusahaan menginvestasinya keberbagai bidang usaha untuk memperluas dan memperbesar kegiatan usaha bisnisnya, sehingga dengan adanya tingkat kebutuhan dana yang besar maka, penambahan utang juga semakin meningkat. Hal ini sepadan dengan tiga fungsi utama manajemen keuangan, yang salah satunya yaitu fungsi mendapat dana yang menyangkut keputusan pembelanjaan atau pendanaan (Sugiarto,2009).

Suatu perusahaan jika dalam memenuhi kebutuhan dananya mengutamakan pemenuhan dengan sumber dari perusahaan akan mengurangi ketergantungannya kepada pihak luar (bank). Konsekuensinya, modal asing hanya digunakan sebagai pelengkap apabila dana yang diperlukan kurang mencukupi. Peran ini diperhatikan dan dilaksanakan oleh manajer keuangan dengan tetap memperhatikan biaya modalnya. Apakah kebutuhan dana perusahaan dipenuhi dengan modal sendiri ataukah dipenuhi dengan modal asing, hal ini karena untuk penggunaan setiap modal yang berbeda-beda tentu memiliki tingkat resiko yang berbeda pula. Beberapa faktor yang diperhatikan oleh perusahaan Esperanca Timor-Oan adalah bagaimana menentukkan sumber pendanaan. Penentuan sumber dana dilakukan oleh manajer keuangan dana pembiayaan seluruh kegiataan bisnis yaitu bagaimana meningkatkan penjualan, memperluas ekspansi bisnis dan meningkatkan profitabilitas perusahaan di masa sekarang maupun masa yang akan datang. Dengan adanya peluang bisnis yang sangat luas di Timor-Leste, maka perusahaan Esperanca Timor-Oan berusaha maksimal untuk memperluas kegiataan bisnis, hal ini berdampak pada kebutuhan dana, maka perusahaan memerlukan tambahan dana yang berasal dari bank.

Selain itu, beberapa faktor yang perlu diperhatikan oleh manajemen keuangan perusahaan Esperanca Timor-Oan dalam menentukan sumber pendanaan. Menurut Sartono (2008), faktorfaktor tersebut adalah tingkat penjualan, struktur aktiva, tingkat pertumbuhan perusahaan, 


\section{E-Jurnal Ekonomi dan Bisnis Universitas Udayana 8.1 (2019): 23-40}

profitabilitas, variabel laba dan perlindungan pajak, ukuran perusahaan, kondisi ekonomi perusahaan dan ekonomi makro.

Perusahaan yang mempunyai profit yang tinggi, akan menggunakan hutang dalam jumlah yang rendah. Menurut (Weston dan Brigham,1998 dalam Kesuma 2009), perusahaan dengan tingkat return on assets yang tinggi, umumnya menggunakan hutang dalam jumlah yang relatif sedikit. Hal ini disebabkan dengan return on assets yang tinggi tersebut, memungkinkan bagi perusahaan melakukan permodalan dengan laba ditahan saja.

Perusahaan akan lebih cenderung untuk menggunakan sumber pendanaan internal yaitu dari laba ditahan dan depresiasi terlebih dahulu, dari pada dana eksternal dalam aktivitas pendanaan. Hanya jika perusahaan tidak memiliki dana internal yang memadai, maka dana eksternal akan dipilih sebagai alternatifnya. Jika dana eksternal dibutuhkan maka perusahaan akan menerbitkan sekuritas paling aman terlebih dahulu,

Menurut Sujoko (2007) ukuran Perusahaan yang besar menunjukkan perusahaan mengalami perkembangan sehingga investor akan merespon positif dan nilai perusahaan akan meningkat. Pangsa pasar relatif menunjukkan daya saing perusahaan lebih tinggi dibanding pesaing utamanya. Investor akan merespon positif sehingga nilai perusahaan akan meningkat.

Perusahaan besar yang sudah well-estabilished akan mudah memperoleh modal di pihak kreditor (Bank) dibanding dengan perusahaan kecil. Karena kemudahan akses tersebut berarti perusahaan besar seperti Esperança Timor Oan memiliki fleksibilitas yang lebih besar pula (Sartono, 2012). Hasil penelitian (Mada, 2013) memberikan hasil yang konsisten bahwa ukuran perusahaan berpengaruh negatif signifikan terhadap tingkat profitabilitas yang dimiliki oleh perusahaan. Sedangkan hasil penelitian Joni dan Lina (2011) menunjukkan hasil yang berbeda yaitu: ukuran perusahaan berpengaruh positif terhadap profitabilitas.

Firm size atau ukuran perusahaan ditunjukkan oleh seberapa besar penjualan atau besarnya asset yang dihasilkan perusahaan dalam kinerja keuangannya. Hal tersebut diidentifikasi sebagai tolak ukur besar kecilnya ukuran dari suatu perusahaan. Ukuran perusahaan akan memberikan pandangan tersendiri terhadap investor perusahaan terkait dengan kondisi perusahaan di masa depan. Ukuran perusahaan memiliki peranan yang sangat penting dalam menentukan besar kecilnya tingkat profitabilitas yang di miliki perusahaan. Para peneliti memiliki pandangan bahwa perusahaan dengan ukuran besar memiliki sedikit kemungkinan untuk menuju kebangkrutan dibandingkan dengan perusahaan kecil.

Hal tersebut dikarenakan perusahaan besar akan lebih terdiversifikasi dalam mengembangkan unit bisnisnya dibandingkan perusahaan kecil.(Amidu, 2007). Hal ini sejalan dengan temuan Chen dan Strange, (2008) yang menyatakan bahwa banyak penelitian dalam perusahaan besar lebih banyak menggunakan utang dibandingkan perusahaan kecil, karena perusahaan besar memiliki arus kas yang lebih stabil, sehingga akan mampu mengurangi risiko dari penggunaan utang. Hal tersebut memberikan sinyal bahwa perusahaan besar akan mudah memperoleh akses yang lebih mudah dan lebih luas masuk pasar modal sehingga memperoleh jumlah dana dengan biaya yang lebih rendah jika dibandingkan dengan perusahaan kecil. 
Merurut pendapat Weston \& Copeland (1992: 53), bahwa dengan menggunakan leverage, nilai perusahaan akan meningkat karena adanya manfaat perlindungan pajak. Dalam perhitungan pajak, bunga hutang dikurangkan terlebih dahulu, ini berarti penggunaan hutang mengakibatkan keringanan pajak untuk arus kas perusahaan. Jadi nilai perusahaan akan naik dengan naiknya hutang jika satu-satunya pengaruh terhadap operasi perusahaan adalah pengaruh perlindungan pajak akibat naiknya hutang.

Pada umumnya, semakin tinggi tingkat penggunaan utang, maka profitabilitas terjadinya financial distress semakin besar. Financial distress adalah kondisi dimana perusahaan mengalami kesulitan keuangan dan terancam bangkrut. financial distress terdiri dari dua macam yaitu: Direct cost of financial distress dan indirect cost of financial distress. Yang dimaksud direct cost of financial distress adalah biaya kebangkrutan atau bankruptcy costs, meliputi biaya likuiditas, keterpaksaan menjual aktiva dengan harga yang lebih rendah dari pada harga pasar, dan lain-lain. Sedangkan yang termasuk dalam indirect costs of financial distress adalah biaya yang timbul karena manajemen cenderung menghabiskan waktu untuk menghindari kebangkrutan daripada membuat keputusan perusahaan (Lukas, 2003). Hal ini karena semakin tingginya penggunaan utang dengan beban tetap berupa biaya bunga yang semakin besar, tidak diikuti dengan kenaikan pendapatan. Perusahaan akan terancam bangkrut apabila didalam penggunaan utang, perusahaan tidak dapat memenuhi kewajiban-kewajiban yang muncul akibat dari penggunaan utang tersebut. Namun pada perusahaan Eto penggunakan utang yang semakin besar dikarenakan perusahaan melakukan ekspansi bisnis, namun dapat meningkatkan profitabilitas perusahaan.

Signally theory, Bhattacarya (1979) dalam Sujoko (2007) mengemukakan bahwa profitabilitas yang tinggi menunjukkan prospek perusahaan yang bagus sehingga investor akan merespon positif dan nilai perusahaan akan meningkat. Pembayaran deviden yang semakin meningkat menunjukkan prospek perusahaan semakin bagus sehingga investor akan tertarik untuk membeli saham dan nilai perusahaan akan meningkat.

Untuk meningkatkan profit atau asset perusahaan Eto, perusahaan tersebut melakukan investasi dalam bentuk portofolio. Perusahaan tersebut juga terjun ke bisnis internasional. dan juga menginvestasikan dananya ke berbagai bidang bisnis. Sehingga meninbulkan pada faktor modal, sehingga untuk memenuhi kebutuhan akan modal perusahaan, masih memerlukan dana dari pihak bank.

Pertumbuhan perusahaan menunjukkan bagaimana suatu perusahaan mampu meningkatkan penjualan perusahaannya. Peningkatan penjualan perusahaan akan mencerminkan bagaimana perusahaan dapat bekerja secara optimal dalam mengelolah kekayaan perusahaan. Pertumbuhan perusahaan juga ditandai dengan adanya peningkatan perubahan aktiva baik aktiva lancer, aktiva tetap yang dimiliki perusahaan setiap tahun. Dengan adanya peningkatan pertumbuhan perusahaan, maka perusahaan akan memperoleh suatu laba dari aktivitas operasi asset perusahaan atau hasil dari tingkat turnover on asset perusahaan. Kemampuan suatu perusahaan menghasilkan 
laba dan mengembangkan asset perusahaan terlihat dari bagaimana peran manajemen dalam melakukan keputusan investasi yang tepat bagi perusahaan.

Perusahaan yang memiliki kesempatan untuk berkembang yang tinggi akan memiliki nilai investasi dalam jumlah yang besar, yang ditandai dengan adanya penambahan aktiva tetap. Pendirian pabrik baru, program pengembangan riset atau research and development, dalam rangka menemukan teknologi baru dan memperluas pasar ekspansi bisnis yang baru dan yang akan dikembangkan di masa depan (Setiawan, 2009). Pertumbuhan perusahaan akan menjadi perhatian manajemen dan pemilik perusahaan dalam jangka waktu yang panjang bertujuan untuk memaksimalkan kekayaan pemegang saham yang pada akhirnya akan mampu meningkatkan nilai perusahaan yang sesuai dengan tujuan keputusan investasi perusahaan. Maka dari itu perusahaan Esperanca Timor-Oan Unipessoal Lda. (ETO) memperluas ekspansi bisnis baru terutama Pertamina sesuai standar internasional, dengan menginvestasikan dananya diperusahaan Amerika yaitu Conoc Phlilips sehingga perusahaan sangat membutuhkan dana dari pihak ketiga (Bank) untuk pengembangan perusahaan dengan tujuan yang telah ditentukan di masa-masa mendatang sesuai dengan target perusahaan. (www.eto.tl,2010.

\section{Tujuan Penelitian}

1) Untuk mengetahui signifikansi pengaruh ukuran perusahaan terhadap profitabilitas perusahaan Esperanca Timor Oan lda?

2) Untuk mengetahui signifikansi pengaruh leverage perusahaan terhadap profitabilitas perusahaan Esperança Timor-Oan Lda?.

3) Untuk mengetahui signifikansi pengaruh Likuiditas perusahaan terhadap profitabilitas perusahaan Esperança Timor-Oan Lda?

\section{KAJIAN PUSTAKA}

Menurut Fahmi (2011;20 kinerja keuangan adalah suatu analisis yang dilakukan untuk melihat sejauh mana perusahaan telah melaksanakan dengan menggunakan aturan-aturan pelaksanaan keuangan secara baik dan benar. Sedangkan Mulyadi (2007:2) mengatakan bahwa kinerja keuangan adalah "penentuan secara periodic efektifitas operasional suatu organisasi dan karyawannya berdasarkan sasaran, standar, dan criteria yang ditetapkan sebelumnya'. Pendapat serupa dikemukakan oleh Sawir (2005:1) yang menyatakan bahwa 'kinerja keuangan adalah kondisi yang mencerminkan keadaan keuangan perusahaan berdasarkan sasaran, standard an criteria yang ditetapkan ". Hal ini sangat penting agar sumber daya digunakan secara optimal dalam menghadapi perubahan lingkungan yang ada diperusahaan.

Berdasarkan beberapa para ahli dapat ditarik kesimpulan bahwa kinerja keuangan merupakan suatu prestasi yang dicapai oleh perusahaan, untuk selanjutnya dilakukan penilaian kinerja keuangan dengan cara melakukan analisis tentang baik buruknya keputusan sebagai gambaran 
mengenai hasil kinerja dan operasi perusahaan yang tertuang dalam laporan keuangan perusahaan berdasarkan pada aturan -aturan yang berlaku secara baik dan benar sehingga dapat mencapai tujuan yang di harapkan perusahaan .

\section{Pentingnya Kinerja Perusahaan}

Penilaian kinerja pada dasarnya merupakan perilaku manusia dalam melaksanakan peran yang dimainkannya dalam mencapai tujuan perusahaan. Penilaian kinerja dilakukan bertujuan untuk memotivasi karyawan dalam mencapai sasaran perusahaan dan dalam mematuhi standar perilaku yang telah ditetapkan sebelumnya, agar membuahkan tindakan dan hasil yang diinginkan. Penilaian kinerja perusahaan penting dilakukan oleh manajemen perusahaan, pemerintah dan pihak lain yang berkepentingan. Dengan mendeteksi kinerja keuangan perusahaan, dapat mengidentifikasi kondisi perusahaan selama periode tertentu.

\section{Manfaat Penilaian Kinerja perusahaan}

Adapun manfaat dari penilaian kinerja perusahaan adalah sebagai berikut:

1) Untuk mengukur prestasi yang dicapai oleh perusahaan selama yang mencerminkan tingkat keberhasilan pelaksanaan kegiatan bisnisnya.

2) Selain digunakan untuk melihat kinerja perusahaan secara keseluruhan, maka pengukuran kinerja juga dapat digunakan untuk menilai kontribusi bagian dalam pencapaian tujuan perusahaan secara keseluruhan.

3) Dapat digunakan sebagai dasar penentuan strategis perusahaan dimasa mendatang.

4) Memberikan petunjuk dalam pembuatan keputusan dan kegiatan perusahaan pada umumnya dan divisi atau bagian perusahaan pada umumnya.

5) Sebagai dasar penentuan kebijaksanaan penanaman modal agar dapat meningkatkan efisiensi dan produktivitas perusahaan.

\section{Tujuan Penilaian Kinerja keuangan Perusahaan}

1) Untuk mengetahui tingkat likuiditas, yaitu kemampuan perusahaan untuk memperoleh kewajiban keuangannya yang harus segera dipenuhi atau kemampuan perusahaan untuk memenuhi keuangannya pada saat ditagih.

2) Untuk mengetahui tingkat solvabilitas, yaitu kemampuan perusahaan untuk memenuhi kewajiban keuangannya apabila perusahaan tersebut dilikuidasi baik kewajiban keuangan jangka pendek maupun jangka panjang selama periode tertentu.

3) Untuk mengetahui tingkat profitabilitas, yaitu menunjukkan kemampuan perusahaan untuk menghasilkan laba.

4) Untuk mengetahui tingkat stabilitas usaha, yaitu kemampuan perusahaan untuk melakukan usahanya dengan stabil, yang diukur dengan mempertimbangkan kemampuan perusahaan 
untuk membayar beban bunga atas hutang-hutangnya termasuk membayar kembali pokok hutangnya tepat pada waktunya.

\section{Profitabilitas}

Dalam meningkatkan profitabilitas pada perusahaan. Setiap Perusahaan melakukan ekspansi keberbagai bidang bisnis. Yaitu bagaimana perusahaan menggunakan kemampuan sumber daya manusia yang dimiliki dalam mengelolah sumber daya yang dimilikinya.

Profitabilitas atau sering disebut rentabilitas adalah yang menggambarkan kemampuan perusahaan untuk mendapatkan laba melalui semua kemampuan perusahaan dan sumber daya yang ada. Seperti kegiatan penjualan, kas, modal, jumlah karyawan, jumlah cabang yang dimiliki perusahaan ataupun anak perusahaan dan sebagainya. Rasio yang menggambarkan kemampuan perusahaan menghasilkan laba disebut juga operating ratio. Rasio provitabilitas merupakan rasio yang mengukur kemampuan perusahaan dalam menghasilkan laba (Profitabilitas) pada tingkat penjualan, aktiva dan modal. Cara pengukurannya adalah dengan proksi ROA,yaitu membangdingkan laba bersih setelah pajak dengan total terhadap penjualan pada periode sebelumnya (Kesuma,2009).

\section{Ukuran perusahaan (firm size)}

Ukuran perusahaan dapat digambarkan pada kemampuan keuangan perusahaan pada periode tertentu, baik berdasarkan asset dalam bentuk aktiva lancar maupun aktiva tetap yang dimiliki.Ukuran perusahaan merupakan gambaran kemampuan financial perusahaan dalam suatu periode tertentu berdasarkan asset yang dimiliki. ukuran perusahaan yang besar, dianggap sebagai suatu indikator yang menggambarkan tingkat risiko yang tinggi bagi perusahaan tersebut. Besarnya ukuran perusahaan dapat dinyatakan dalam total aktiva, penjualan, dan kapitalisasi pasar. semakin besar maka akan semakin besar ukuran perusahaan tersebut. Total aktiva, penjualan dan kapitalisasi pasar dapat digunakan untuk menentukan ukuran perusahaan .(Sudarmadji dan Sularto, 2007).

\section{leverage}

Perusahaan menggunakan dana pihak ketiga (Bank), karena untuk tujuan ekspansi ke berbagai bidang bisnis serta meningkatkan profitabilitas. Dengan perusahaan merupakan penggunaan biaya tetap dalam usaha untuk meningkatkan (lever up) profitabilitas. (J.R.R.Tolkien) atau leverage adalah rasio yang mengukur seberapa efektif (hasil guna) perusahaan menggunakan sumber dayanya. 


\section{Likuiditas}

Perusahaan memiliki kemampuan dalam membiayai kewajiban dalam jangka pendeknya yang jatuh tempo, hal ini dikarena perusahaan memiliki investasi keberbagai bidang bisnis, sehingga keuntungan yang diperoleh dari salah satu bisnis bisa dipergunakan untuk memenuhi kewajibankewajiban pada saat jatuh tempo.

Rasio likuiditas atau liquidity ratio atau sering disebut dengan nama rasio modal kerja merupakan rasio yang digunakan untuk mengukur seberapa likuid suatu perusahaan. Caranya adalah dengan membandingkan seluruh komponen yang ada di aktiva lancar dengan komponen di pasiva lancar (utang jangka pendek)

Rasio ini juga menunjukan kemampuan perusahaan untuk membayar utang-utang (kewajiban) jangka pendeknya yang jatuh tempo. Atau,rasio untuk mengetahui kemampuan perusahaan dalam membiayai dan memenuhi kewajiban/utang pada saat ditagih. Likuiditas menurut Wild, Subramanyam, dan Hasley (2005:185) "merupakan kemampuan untuk mengubah aktiva menjadi kas atau kemampuan untuk memperoleh kas".

Rasio Likuiditas menurut Agus Sartono (1997:62)“adalah mengukur kemampuan perusahaan untuk memenuhi kewajiban keuangan jangka pendek tepat pada waktunya".

Rasio-rasio yang dimaksudkan untuk mengukur likuiditas perusahaan (current ration,acip test ratio). Menurut (Houston \& Brigham, 2001) adalah rasio yang menunjukkan hubungan antara asset lancar yang dimiliki perusahaan dengan kewajiban lancar yang dimiliki perusahaan.

\section{Pengaruh Ukuran Perusahaan Terhadap Profitabilitas}

Perusahaan yang besar akan lebih mudah memperoleh modal dari pihak kreditor (Bank) dibanding dengan perusahaan kecil, karena kemudahan akses tersebut berarti perusahaan besar memiliki fleksibilitas yang lebih besar pula (sartono, 2010). Semakin tinggi pula dana yang dibutuhkan untuk membiaya kebutuhan untuk membiaya kebutuhan perusahaan. Sehingga kecenderungan penggunaan modal asing juga akan semakin meningkat. Hasil penelitian sebelumnya menyatakan bahwa ukuran perusahaan berpengaruh positif dan negatif terhadap profitabilitas dan oleh karena itu dapat diambil hipotesis pada penelitian ini sebagai berikut;

Ukuran perusahaan berpengaruh signifikan terhadap profitabilitas perusahaan

Secara teoritis, perusahaan yang ukurannya relatif besar, kecendrungan penggunaan dana eksternal juga semakin besar. Hal ini disebabkan kebutuhan dana juga semakin meningkat seiring dengan pertumbuhan perusahaan. Sehingga menurut hipotesis trade off theory, semakin besar perusahaan maka perusahaan dapat memakai utang lebih banyak, hal itu disebabkan karena perusahaan besar memiliki tingkat default risk yang rendah. Semakin rendahnya risiko perusahaan akan menyebabkan biaya utang perusahaan skala besar lebih kecil jika di bandingkan dengan perusahaan skala kecil, rendahnya risiko perusahaan tersebut akan mendorong perusahaan untuk menggunakan utang lebih banyak. Sehingga dapat dikatakan bahwa ukuran perusahaan ( firm size) 
berpengaruh positif terhadap profitabilitas. Beberapa hasil penelitian terdahulu menunjukkan inkonsistensi pada hasil yang berbeda, yaitu ukuran perusahaan dalam penelitian Ditmar et al (2003) berpengaruh negatif dan signifikan terhadap profitabilitas, sedangkan penelitian Rifki Ismal (2008) memberikan bukti tidak signifikan.

\subsection{Pengaruh leverage terhadap profitabilitas}

Leverage akan mempengaruhi kinerja perusahaan dan menyebabkan apresiasi . Leverage yang terlalu tinggi mempunyai dampak buruk terhadap kinerja perusahaan, karena tingkat hutang yang semakin tinggi berarti beban bunga perusahaan akan semakin besar dan mengurangi keuntungan (profit) perusahaan. (Robert Ang, 1997). Maka leverage berpengaruh posistif dan negatif terhadap profitabilitas pada perusahaan. Rasio leverage dalam penelitian Papaioannou et al (1992) berpengaruh negatif signifikan terhadap profitabilitas, sedangkan penelitian Kustiadi (2006) memberikan bukti tidak signifikan.

Penelitian mengenai pengaruh leverage sudah pernah dilakukan oleh beberapa peneliti sebelumnya. Berdasarkan nilai adjusted $R 2$ penelitian terdahulu, dapat disimpulkan bahwa financial leverage lebih besar menjelaskan ROE (Return on Equity) daripada EPS (Earning per Share). Oleh karena itu, penulis tertarik menggunakan ROE (Return on Equity) sebagai variabel terikat dari penelitian ini. Return on equity merupakan suatu pengukuran dari penghasilan (income) yang tersedia bagi para pemilik perusahaan (baik pemegang saham biasa maupun saham preferen) atas modal yang diinvestasikan di dalam perusahaan (Syamsuddin, 2009: 64). Return on equity merupakan salah satu indikator penting yang sering digunakan oleh investor untuk menilai tingkat profitabilitas perusahaan sebelum melakukan investasi.

\subsection{Pengaruh likuiditas terhadap profitabilitas}

Penelitian terdahulu menyatakan bahwa likuiditas berpengaruh positif dan negatif terhadap profitabilitas. (Riyanto,2010) rasio ini digunakan untuk mengukur kemampuan perusahaan untuk memenuhi kewajiban financial jangka pendeknya. Likuiditas dalam penelitian ini diwakili oleh quick ratio dengan alasan bahwa quick ratio lebih mencerminkan kemampuan perusahaan untuk melunasi hutang lancarnya dimana quick ratio ini dapat memberikan gambaran seberapa jauh tuntutan dari kreditor jangka pendek dapat dipenuhi oleh aktiva lancar tanpa memperhitungkan nilai persediaan yang diperkirakan menjadi uang tunai dalam periode yang sama dengan jatuh tempo utang. Disamping itu juga didasarkan pada alasan bahwa semakin tinggi quick ratio maka semakin tinggi pula kemampuan perusahaan untuk membayar kewajibannya. Ini akan berdampak pada semakin meningkatnya kepercayaan investor dalam menanamkan dananya pada perusahaan sehingga saham perusahaan meningkat dan return juga semakin meningkat. Hasil penelitian Ria (2011). 
Mengetahui bagaimana kondisi keuangan perusahaan Esperanca Timor-Oan Unipessoal Lda, diperlukan laporan keuangan yang disusun setiap akhir periode yaitu pada peride 2010-2012. Laporan keuangan tersebut dibuat oleh manajemen dengan tujuan untuk mempertanggungjawabkan tugas-tugas yang diberikan kepada manajer. Laporan keuangan yang dimaksud berupa neraca dan laporan laba-rugi. Neraca menunjukkan posisi keuangan (aktiva, kewajiban dan ekuitas) perusahaan pada saat tertentu, sedangkaan laporan laba rugi menunjukkan kemampuan perusahaan dalam menghasilkan laba yang telah terjadi pada periode tertentu, kemudian laporan keuangan tersebut dianalisis untuk mengetahui secara jelas posisi keuangan dengan menggunakan analisis rasio.

Mengingat peranan penting analisis laporan keuangan untuk menilai laju usaha dan perkembangan usaha perusahaan Esperanca Timor-Oan sangatlah besar, maka pengetahuan yang diimbangi kemahiran dalam menganalisis dan menginterprestasikan data-data dari laporan keuangan sangat bermanfaat bagi perusahaan Esperanca Timor-Oan Unipessoal, Lda sebagai acuan dalam pengambilan keputusan yang terkait tentang kebijakan perusahaan untuk memajukan dan mengembangkan perusahaan tersebut di masa mendatang serta dapat meningkatkan profit perusahaan.

\section{Hipotesis Penelitian}

Berdasarkan temuan penelitian tersebut dapat dirumuskan hipotesisis sebagai berikut;

H1. Ukuran perusahaan (Firm size) berpengaruh positif signifikan terhadap profitabilitas perusahaan Esperanca Timor-Oan Unipessoal, Lda.selama periode 2010-2012. Hal ini menunjukkan bahwa perusahaan Esperanca Timor-Oan melakukan ekspansi keberbagai bidang bisnis sehingga memperbesar jumlah hutang seiringnya dengan besarnya ukuran perusahaan Esperanca Timor-Oan di masa mendatang.

Menurut Sartono (2010) mengenai ukuran perusahaan (Firm Size) pada penelitian terdahulu menunjukkan bahwa ukuran perusahaan berpengaruh positif signifikan terhadap profitabilitas. temuan sama yang juga dilakukan oleh Sheikh dan Wang (2011) yang menyatakan bahwa ukuran perusahaan berpengaruh positif signifikan terhadap profitabilitas yang diukur dengan menggunakan Total Asset. Sesuai dengan teori trade off dimana perusahaan dengan skala yang besar sebaiknya mengoptimalkan penggunaan utang yang tinggi sesuai dengan kemampuannya dalam mendiversifikasi risiko dan dalam mengambil manfaat penghematan pajak dalam pembayaran bunga atas utang tersebut.

$\mathrm{H}$ 2. Leverage berpengaruh positif signifikan terhadap profitabilitas perusahaan pada perusaahaan Esperanca Timor-Oan Unipessoal,Lda selama periode 2010-2012. Menurut Guney et al (2009) menunjukkan bahwa leverage pada penelitian terdahulu menunjukkan bahwa leverage pengaruh positif signifikan. Hal ini menunjukkan bahwa perusahaan Esperanca Timor-Oan menggunakan hutang dalam jumlah besar untuk meningkatkan 
profitabilitas dimasa mendatang. Sejalan dengan temuan yang dilakukan oleh Harley (1992) yang menunjukkan bahwa leverage berpengaruh positif signifikan terhadap Profitabilitas.

H3. Likuiditas berpengaruh positif signifikan terhadap profitabilitas perusahaan Esperanca Timor-Oan Unipessoal Lda. Pada periode 2010-2012. Namun berbeda dengan hasil penelitian Wijaya (2012) yang menunjukkan bahwa likuiditas berpengaruh positif dan negatif. Hal ini memunjukkan bahwa besarnya ukuran perusahaan Esperanca Timor-Oan, dan ekspansi ke berbagai bidang bisnis, maka perusahaan memiliki kemampuan untuk bisa mengatasi hutang pada saat jatuh tempo. Dan sejalan dengan hasil penelitian oleh Riyanto (2010) yang menyatakan bahwa likuiditas berpengaruh positif signifikan terhadap profitabilitas.

\section{METODE PENELITIAN}

Dalam penelitian ini menggunakan jenis penelitian assosiatif dengan hubungan kausal. Pendekatan yang dipergunakan adalah kuantitatif karena pemaknaan variabel maupun hubungan antara variabel didasarkan pada hasil pengukuran secara kuantitatif. Dalam penelitian ini akan menguji hubungan kausal atau pengaruh dari variable pengaruh ukuran perusahaan, leverage dan liquiditas terhadap profitabilitas pada perusahaan Esperanca Timor-Oan di Dili Timor-Leste. Data yang digunakan dalam penelitian diambil langsung dari perusahaan ETO. Adapun pergerakan Total Asset, Debt To Equity Ratio (DER), Quick Ratio dan Return on Asset (ROA) pada perusahaan di masing-masing periode pada tahun 2010-2012.

\section{Lingkup Penelitian}

Lokasi penelitian dilakukan di perusahaan Esperanca Timor-Oan Unipesoal Lda. dengan pengambilan data secara langsung di menajer keuangan, data yang diambil yaitu; berupa Laporan Rugi laba dan Neraca dari Tahun 2010-2012.

\section{V . IDENTIFIKASI VARIABEL}

variabel-variabel dalam penelitian ini dapat diidentifikasi sebagai berikut;

1) Variabel dependen (variabel $Y$ )

Variabel dependen adalah variabel yang menjelaskan atau dipengaruhi oleh variabel independen. Variabel dependen dalam penelitian ini adalah Profitabilitas (ROA).

2) Variabel Independent (Variabel $X$ )

Variabel independen merupakan variabel yang diduga sebagai sebab variabel yang diduga sebagai sebab variabel dependen atau terpengaruhnya variabel dependen. Variabel 
independen dalam penelitian ini adalah ukuran perusahaan (X1), leverage (X2) dan likuiditas (X3)

\section{prosedur pengumpulan data}

Data yang digunakan adalah data sekunder. Data sekunder dalam penelitian ini berupa laporan keuangan yaitu laporan rugi laba dan neraca di perusahaan Esperança Timor-Oan (ETO) tahun 2010-2012.

\section{Metode pengumpulan data}

Metode pengumpulan data yang digunakan dalam penelitian ini adalah observasi merupakan metode pengumpulan data dimana peneliti tidak terlibat dan hanya sebagai pengamat independent. Dengan metode ini semua data diperoleh melalui pengumpulan data dengan cara mengamati, mencatat serta uraian-uraian dari buku-buku, karya ilmiah berupa jurnal, tesis dan dokumen-dokumen yang terkait dengan tesis peneliti Tahun 2010-2012.

\section{Metode Analisis Data}

Teknik analisis data yang digunakan dalam penelitian ini adalah dengan menggunakan Regresi Linear Berganda. Regresi Linear Berganda adalah teknik untuk menentukan korelasi antara dua atau lebih variable bebas (independent) dengan variable terikat (dependent).

\section{Analisi Regresi Liner}

persamaan regresi sebagai berikut:

Profitabilitas $=0,0324 \mathrm{X} 1+0,047 \mathrm{X} 2-0,0351 \mathrm{X} 3$

Y1 = Profitabilitas

$\mathrm{a}=$ Nilai $\mathrm{Y}$ pada potongan antara garis linear dengan sumbu vertikal $\mathrm{Y}$

$\mathrm{X} 1=$ ukuran perusahaan

$\mathrm{X} 2$ = Leverage

X3 = Likuiditas

b1,b2 dan b3 = slope yang berhubungan dengan variabel X1, X2 dan X3

ei $=$ Error Tearm, yaitu tingkat kesalahan penduga dalam penelitian

Menurut Suyana Utama (2007:89) sebelum model regresi digunakan untuk memprediksi beberapa peneliti menganggap perlu menguji kelayakan model yang dibuat. Untuk itu dilakukan 
pengujian asumsi klasik yang meliputi Uji Normalitas, Uji Autokorelasi, Uji Multikolinieritas, dan Uji Heteroskedastisitas.

\section{Uji Normalitas}

Uji normalitas bertujuan untuk menguji apakah dalam residual dari model regresi yang dibuat berdistribusi normal atau tidak. Model regresi yang baik adalah memiliki distribusi residual yang normal atau mendekati normal.

\section{Uji Autokorelasi}

Untuk melacak adanya korelasi auto atau pengaruh data dari uji pengamatan sebelumnya dalam model regresi di atas dilakukan uji autokorelasi. Jika suatu model regresi mengandung gejala autokorelasi, maka prediksi yang dilakukan dengan model tersebut akan tidak baik, atau dapat memberikan hasil prediksi yang menyimpang.

\section{Uji Multikolinearitas}

Uji multikolinearitas bertujuan untuk menguji apakah pada model regresi ditemukan adanya korelasi antar variabel bebas. Model regresi yang baik seharusnya tidak terjadi korelasi di antara variabel bebas. Model regresi yang baik adalah bebas dari gejala multikolinier.

\section{Uji Heteroskedastisitas}

Uji heteroskedastisitas bertujuan menguji apakah dalam model regresi terjadi ketidaksamaan varians dari residual satu pengamatan ke pengamatan yang lain. Model regresi yang baik adalah yang tidak mengandung gejala heteroskedastisitas atau mempunyai varians homogen.

\section{HASIL PENELITIAN DAN PEMBAHASAN}

Variabel yang dioperasikan dalam penelitian ini terdiri dari variabel eksogen, dan variabel endogen dependan. Variabel profitabilitas (Y) diproksikan dengan rasio profitabilitas yang dioperasikan sebagai variabel dependen. Variabel Likuiditas (X3) diproksikan dengan Quick Ratio (QR) yang diopersasikan sebagai variabel intervening. Variabel ukuran perusahaan (X1) diproksikan dengan Total Asset dan variabel (X2) diproksikan dengan Debt to Equity (DER) yang dioperasikan dengan variabel eksogen.

Variabel ukuran perusahaan (X1) memiliki rata-rata hitung (mean) 2.946.095 artinya rata-rata ukuran perusahaan selama periode 2010-2012 adalah sebesar 2.946.095 pertahun. Standar deviasi (simpan baku) pada variabel Ukuran perusahaan (X1) adalah 1.318.877. Artinya selama tiga tahun 
pengamatan, variasi ukuran perusahaan Esperanca Timor-Oan Unipessoal.Lda menyimpang dari rata-ratanya sebesar 1.318.877 Perbulan. Tingkat pengukuran perusahaan terendah (Minimum) selama periode pengamatan yaitu 30.321 ukuran perusahaan tertinggi (Maksimun) selama periode pengamatan yaitu pada perusahaan Esperanca Timor-Oan sebesar 5.109.229 perbulan.

Variabel Leverage (X2) yang diproksikan dengan Debt to Total Equity (DER) memiliki ratarata hitung (Mean) sebesar 0,1354 artinya rata-rata leverage perusahaan selama periode 2010-2012 adalah sebesar 0,1354 pertahun. Standar deviasi (simpangan baku) variabel leverage perusahaan adalah 0,0855 artinya selama tiga tahun pengamatan di perusahaan Esperanca Timor-Oan Unipessoal.Lda ( ETO) menyimpang dari rata-rata nya sebesar 0,0855. Leverage perusahaan terendah (Minimun) selama periode pengamatan diperusahaan ETO sebesar 0,0700 selama periode pengamatan yaitu diperusahaan Esperanca Timor-Oan sebesar 0,0700. Leverage tertinggi (Maksimun) selama peride pengamatan yaitu sebesar 0,5700 persen.

Variabel likuiditas (X3) yang diproksikan dengan Quick Ratio (QR) memiliki rata-rata hitung (mean) sebesar 8,6247 artinya rata-rata likuiditas perusahaan selama periode 2010-2012 adalah sebesar 8,6247 pertahun. Standar deviasi (simpangan baku) variabel likuiditas perusahaan Esperanca Timor-Oan (ETO) menyimpang rata-ratanya sebesar 3,2965 artinya selama tiga tahun pengamatan variasi likuiditas perusahaan Esperanca Timor-Oan dari rata-ratanya sebesar 3,2965 persen. Likuiditas perusahaan Esperanca Timor-Oan terendah (Minimun) selama periode pengamatan sebesar 0,1800 persen. Likuiditas perusahaan tetinggi (Maksimun) selama periode pengamatan sebesar 13.4200 persen.

Variabel profitabilitas (Y) memiliki rata-rata hitung (mean) sebesar 0,0087 artinya rata-rata profitabilitas perusahaan selama periode 2010-2012 sebesar 0,0087 persen per tahun. Standar deviasi (simpangan baku) variabel profitabilitas adalah 0,0123 artinya selama tiga tahun pengamatan variasi profitabilitas perusahaan menyimpang dari rata-ratanya sebesar 0,123 persen. Profitabilitas terendah (Minimun) selama peride pengamatan sebesar 0,0001 persen. Profitabilitas perusahaan (Maksimun) selama periode pengamatan pada perusahaan Esperanca Timor-Oan sebesar 0,0547 persen.

\section{Uji Hipotesis pertama}

$\mathrm{Ho}=\beta 1=0$, tidak ada pengaruh signifikan pada variabel total asset terhadap profitabilitas (ROA) $\mathrm{H} 1=\beta 1>0$, ada pengaruh signifikan pada variabel total asset terhadap profitabilitas (ROA).

Total Asset berpengaruh negatif signifikan terhadap profitabilitas (ROA) diperusahaan Esperanca

Timor-Oan.

\section{UJi Hipotesis kedua}

Ho $=\beta 2=0$, tidak adanya pengaruh signifikan pada variabel debt to equity (DER) terhadap variabel profitabilitas (ROA).

$\mathrm{H} 1=\beta 2>0$, ada pengaruh signifikan pada variabel debt to equity ratio (DER 
Debt to Equity Ratio (DER) berpengaruh positif signifikan terhadap variabel profitabilitas (ROA).di perusahaan ETO.

\section{UJi Hipotesis ketiga}

Ho $=\beta 3=0$, tidak ada pengaruh signifikan pada variabel quick ratio $(\mathrm{QR})$ terhadap profitabilitas (ROA).

$\mathrm{H} 1=\beta 3=0$, ada pengaruh signifikan pada variabel quick ratio $(\mathrm{QR})$ terhadap variabel profitabilitas (ROA) diperusahaan Esperanca Timor-Oan.

Variabel quick ratio (QR) berpengaruh negatif signifikan terhadap variabel profitabilitas diperusahaan Esperanca Timor-Oan (ETO).

\section{PEMBAHASAN}

1). Hasil penelitian ini menunjukkan bahwa variabel ukuran perusahaan berpengaruh negatif tidak signifikan terhadap profitabilitas diperusahaan Esperanca Timor-Oan unipessoal.Lda tahun 20102012. Hal ini menunjukkan bahwa semakin besar ukuran perusahaan, tidak mampu meningkatkan profitabilitasnya, malah mengakibatkan menurununya profitabilitas perusahaan, walaupun tidak nyata. Ini berarti bahwa pada perusahaan Esperanca Timor-Oan Unipessoal.Lda terjadi pengelolaan dana yang kurang efisien.

2). Hasil penelitian menunjukkan bahwa variabel leverage berpengaruh positif signifikan terhadap variabel profitabilitas pada perusahaan Esperanca Timor-Oan pada periode 2010-2012. Hal ini menunjukkan bahwa penggunaan hutang yang semakin besar pada perusahaan Esperanca TimorOan unipessoal Lda. Dapat meningkatkan profitabilitasnya, ini berarti penggunaan hutang pada perusahaan Esperanca Timor-Oan Unipessoal Lda. Sudah tetap.

3). Hasil penelitian ini menunjukkan bahwa variabel likuiditas perusahaan berpengaruh negatif signifikan terhadap variabel profitabilitas pada perusahaan Esperanca Timor-Oan Unipessoal Lda pada periode 2010-2012. Hal ini bermakna bahwa meningkatnya likuiditas tidak mampu meningkatkan profitabilitasnya. Malah menurunkan profitabilitas walaupun tidak nyata.

\section{KESIMPULAN DAN SARAN}

Berdasarkan hasil penelitian yang diperoleh, maka terdapat beberapa hal yang dapat disimpulkan dalam penelitian ini yaitu:

1) . Ukuran perusahaan pada perusahaan Esperanca Timor-Oan Unipessoal Lda. berpengaruh negatif tidak signifikan terhadap profitabilitas. ini menunjukkan bahwa semakin besar ukuran perusahaan, tidak mampu meningkatkan profitabilitasnya, malah menurunkan profitabilitas, walaupun tidak nyata. Ini berarti bahwa pada perusahaan Esperanca Timor-Oan Unipessoal Lda. Terjadi pengelolaan dana yang kurang efisien.

2) Leverage berpengaruh positif signifikan terhadap profitabilitas. hal ini menunjukkan bahwa penggunaan hutang yang semakin besar pada perusahaan Esperanca Timor-Oan 
Saran

Unipessoal Lda. dapat meningkatkan profitabilitasnya, ini berarti penggunaan hutang pada perusahaan Esperanca Timor-Oan Unipessoal Lda sudah tepat.

3) Likuiditas pada perusahaan Esperanca Timor-Oan Unipessoal. Lda . berpengaruh negatif tidak signifikan terhadap profitabilitas pada perusahaan Eto pada periode 20102012. Hal ini bermakna bahwa meningkatnya likuiditas tidak mampu meningkatkan profitabilitasnya, malah menurunkan profitabilitas walaupun tidak nyata. Ini berarti bahwa pada perusahaan Esperanca Timor-Oan Unipessoal.Lda terjadi pengelolaan dana khususnya pada aktiva lancar yang kurang efisien.

Berdasarkan hasil penelitian yang diperoleh, maka ada beberapa saran antara lain:

1) Diharapkan kepada peneliti selanjutnya untuk menganalisis variabel ukuran perusahaan, leverage dan likuiditas terhadap profitabilitas menggunakan time log data.

2) Disarankan kepada perusahaan Esperanca Timor-Oan Unipessoal. Lda, untuk tetap memperhatikan jumlah penggunaan hutangnya, karena hasil penelitian yang diperoleh menunjukkan bahwa penggunaan hutang dapat meningkatkan profitabilitas perusahaan.

\section{DAFTAR PUSTAKA}

Adetifa,2014 Corporate Finance and Investment Stategy, Lagos, The Charetered I nstitute of Nogeria $1^{\text {st }}$ adition. Bogor, Ghalia, Indonesia.

Adrianto, (2008), Manajemen Keuangan,Edisi Revisi

Alexano,2012, Cover Designer, Manajemen Keuangan secara Global, Pribadi \& Perseorangan serta Manajemen Keuangan Organisasi,

Amiry dan Atmini, 2008. Determinan Tingkat Hutang serta Hubungan Tingkat Hutang terhadap Nilai Perusahaan: Perspektif Pecking Order Theory. Jurnal Akuntansi dan keuangan Indonesia ,2008. Universitas Brawijaya Malang,2008

Atmaja, 2010, Teori dan Praktek, Manajemen Keuangan Analisis Laporan Keuangan. Htt://www.andipublisher.com.

Brigham, and Gapensky 1994, Financial Managemen, The Dryden Press.

Chen dan Strange, (2006) serta Harlina et al, (2011) Ukuran Perusahaan.www.academia.edu.

Gardner and Mills, 1991,Managing Financial Institution,, The Dryden Press.

Hadar,2010 Menjinakkan Arus Keuangan Global (Taming Global Financial Flows,A Citizen's Guide.

Halsey (2005: 36), Manajemen keuangan Modern, Analisis Perencanaan kebijaksanaan.

Harahap (1999:297), manajemen keuangan modern, Edisi 2, penerbit Salemba 
Horne dan Wachowicz,2013. Fundameentals of financial Management

Iskandar \& Yamin, 2008, Metodologi penelitian pendidikan (kuantitatif dan kualitatif)

Jumingan (2012: 242) ,manajemen keuangan Global, pribadi \& Perseoranga serta Manajemen Keuangan Organisasi dalam Perusahaan, Salemba, Indonesia

Kamaludin, and Indriani,2014, Konsep Pasar dan Penerapannya

Keomn, Scott, Martin, dan Petty (2005:108), Laporan Keuangan Perusahaan, gadjah Mada University Press,2005, leverage dari saham Preferen dan Obligasi.

Lukas, 1994, Manajemen Keuangan, Edisi Pertama, Andi Offset.

Nazir (2003: 54) manajemen keuangan terpadu,edisi 2, jilid 2,

Raharjaputra,2009, Manajemen Keuangan dan Akuntansi

Rasia dan Kim, 2011 A Teoretical Review on the use of the Static Trade off Theory, the pecking Order Theory and Agency Cost Theory of Capital Structure International Research Journal of Financeand Economics ISSN 1450-2887 Issue 63 (2011) htt://www.eurojournal.com/finance.htm

Ridwan dan Kuncoro,2008 Metode Analisis data, analisisi kuantitatif dan kualitatif

Riyanto , 2010 pengaruh Likuiditas terhadap profitabilitas, Manajemen Keuangan ISBN :978-97929-0384 (2010).

Sartono, 2010 pengaruh ukuran perusahaan terhadap profitabilitas, Managemen Keuangan, Edisi 3, Universitas Gadja mada, BPFE, Yogyakarta.

Sarwono dan Suhayati, 2011. Riset Akuntansi Menggunakan SPSS, Graha Ilmu Bandung

Senduperdana,2011, Manajemen Keuangan Bisnis, Wajah Cetak Media

Sudarmadji dan Sularto,2012 Ukuran Perusahaan (Firm Size),Manajemen Keuangan

Sugiyarso dan Winarsi, 2009, Manajemen Keuangan, Edisi ketiga, Mitra, Indonesia

Syamsuddin (2000:39), Manajemen Keuangan, likuiditas perusahaan.

Tolkien (2011), Rasio Leverage, Managemen Keuangan Terpadu, Salemba

Westerfiel \& Jordan (2007: 78), manajemen Keuangan terpadu, Salemba

Weston dan Brigham, 1998 dalam Kesuma 2009, perusahaan dengan tingkat return on asset 
Madalena Maria, L.P. Wiagustini, I.B.Panji Sedana. Pengaruh Ukuran Perusahaan... 